\title{
A new conceptual framework for memorable Airbnb experiences: guests' perspectives
}

\author{
Erose Sthapit, Peter Björk, Dafnis N. Coudounaris and Matthew J. Stone
}

\begin{abstract}
Purpose - This qualitative study aims to explore the activities that guests perform while staying in Airbnbs, emotions associated with these experiences and the components of memorable Airbnb experiences.
\end{abstract}

Design/methodology/approach - An empirical study of a qualitative nature was conducted using a self-administered open-ended questionnaire among tourists who had stayed in an Airbnb in the past three years. Data were collected using two different sources for triangulation purposes, referred to as Studies 1 and 2.

Findings - Many respondents reported conducting similar activities while at home and while staying in an Airbnb, supporting Burch's (1969) spill-over theory. Travellers mostly recalled mundane activities, such as cooking. The results suggest that the spill-over effect is more prevalent in the Airbnb context than in other accommodation types, as one often travels from one's own home to another's home. Respondents associated their Airbnb experience with the positive emotion of joy. Respondents mentioned numerous reasons for having felt joy during their Airbnb experiences, such as sharing the trip with travel companions and spending time with friends.

Practical implications - Airbnb should clearly define host's tasks and responsibilities, hosts should treat guests in a friendly manner, which includes resolving any problems they face in relation to the rental property.

Originality/value - This paper proposes a new conceptual framework for a memorable Airbnb experience, which comprises several components: socialising and bonding with friends and family members, location, the host's hospitality, a homely feeling, home amenities and negative experiences (the poor condition of the room and a dishonest host).

Keywords Emotions, Airbnb, Spill-over, Memorable tourism experience, Memorable Airbnb experience Paper type Research paper

\section{Introduction}

Experiencing something new or different from daily life is inherent in tourism (Lee and Crompton, 1992). Such experiences can be referred to as peak experiences (Quan and Wang, 2004), yet other tourism experiences can seem mundane. As tourism includes both peak and supporting (extension of daily life) experiences, it is misleading to omit everyday practices from tourism (McCabe, 2002). The significant emphasis on peak experiences results in minimal attention being paid to travellers' supporting experiences (McCabe, 2002), like lodging (including Airbnbs), which have the potential to ruin an entire tourist experience. Airbnb is the world's largest alternative accommodation provider and is still growing exponentially globally, including in the Nordic countries (Sthapit and Björk, 2020).

Novelty seeking is an innate quality in travellers and as it is a popular motivation for travel, it might make for an optimally enjoyable tourism experience (Cohen, 1972). However, not all
Erose Sthapit is based at

Research Services,

Haaga-Helia University of

Applied Sciences, Helsinki,

Finland. Peter Björk is based

at the Department of

Marketing, Hanken School of

Economics - Vaasa Campus,

Vaasa, Finland.

Dafnis N. Coudounaris is based at Aalborg University Business School, Aalborg University, Aalborg, Denmark and School of Economics and Business Administration, University of Tartu, Tartu, Estonia. Matthew J. Stone is based at the Department of Recreation, Hospitality and Parks Management, California State University Chico, Chico, California, USA.

Received 1 January 2021 Revised 12 March 2021 1 May 2021

28 May 2021

Accepted 6 June 2021

(c) Erose Sthapit, Peter Björk Dafnis N. Coudounaris and Matthew J. Stone. Published by Emerald Publishing Limited. This article is published under the Creative Commons Attribution (CC BY 4.0) licence. Anyone may reproduce, distribute, translate and create derivative works of this article (for both commercial and non-commercial purposes) subject to full attribution to the original publication and authors. The full terms of this licence maybe seen at http://creativecommons.org/licences/by/4.0/ legalcode 
tourists may display the same degree of hedonistic behaviour, and some may exhibit similar behaviours while at home and while on holiday (Sthapit and Björk, 2017). Thus, novelty seeking may be found not only in new activities but also in new places to conduct routine activities (Smith et al., 2012). In other words, tourism is not a secular ritual but overlaps with regular social life as travellers desire to find home away from home (Larsen et al., 2007), as is often the case with Airbnbs.

Airbnb's service quality is dependent upon each host's hospitality capability (Lalicic and Weismayer, 2018), among other factors, and Airbnb guests are likely to experience varying service quality without service delivery guarantee. Consequently, travellers' Airbnb experiences can vary widely and arouse both positive and negative emotions (Sthapit, 2019). Some studies have underlined the need to examine the emotions that guests associate with their recent Airbnb experience (Sthapit and Jiménez-Barreto, 2018). These emotional states of activation during a trip are associated with memorable experiences (Tung and Ritchie, 2011) and positive experiences are considered the ultimate goal that today's holidaymakers seek to attain (Sthapit et al., 2020).

A memorable tourism experience (MTE) is defined as one that is recalled positively after the event (Kim et al., 2012), but memory researchers believe that negative valence may be more influential than positive valence in producing a strong memory (Kensigner and Schacter, 2006). In addition, although the widespread adoption of the MTE scale has enriched the tourism literature but has been criticised on both theoretical and methodological grounds as well as the explicit dimensions of MTE remain incongruent (Sthapit and Jiménez-Barreto, 2018). Many researchers have concluded that the MTE scale cannot be generalised to more authentic travel population (Chandralal et al., 2015; Sthapit and Jiménez-Barreto, 2018). Numerous studies concerning MTEs have focussed on the replication of the MTE scale and a need exists to identify other decisive variables that impact MTEs in other situations, as it does not account for the effects of other contexts (Stone et al., 2021) or the present Airbnb context. In addition, the existing research on memorable Airbnb experiences is limited and restricted to participants from Western countries (Sthapit and Jiménez-Barreto, 2018) and does not bind together the important concepts proposed in this study (spill-over in terms of activities, positive and negative emotions and memorability).

This study proposes to bridge these gaps in the extant literature and suggest connections between activities (experiences), emotions and memories. It aims to do the following:

- examine possible spill-over from home to away (while staying in an Airbnb) in terms of activities undertaken during an on-site Airbnb experience, based on the spill-over theory (Burch, 1969);

- explore the positive and negative emotions that guests associate with their recent Airbnb experience; and

- build on the existing research into MTEs and Airbnb by examining the memorable positive and negative components that guests recall from their recent Airbnb experience (post-holiday stage).

\section{Literature review}

\section{Airbnb}

Airbnb is the largest peer-to-peer (P2P) accommodation network to date. It is a collection of private rooms, apartments and homes, each owned by an individual owner, located in different places and managed independently (Dogru et al., 2020). Since 2008, Airbnb has expanded to more than 191 countries and currently boasts more than 200 million members (Airbnb, 2019). Airbnb allows property owners to gain additional income by renting out unused rooms, apartments and/or houses. Because of the dispersed ownership and 
management of Airbnb units, accommodation and experiences may vary widely (Sthapit and Björk, 2020). Airbnb can potentially expand supply wherever houses and apartment buildings already exist and individual hosts solely determine the prices of their Airbnb listings. Airbnb has become a key competitor of not only other online travel agents (e.g. Expedia) but also traditional hotels (Dogru et al., 2020).

\section{Spill-over theory and activity participation while at home and at the destination (away)}

Wilensky (1960) introduced spill-over theory and proposed that perceptions, attitudes and behaviours from one's social locale can be exhibited in another setting as a replication of one's skills and experiences. Behaviours, emotions, attitudes or stresses carry over from one life domain into another, such as from family to work (Rothbard and Dumas, 2006). Work may also influence non-work domains such as family (Boswell and Olson-Buchanan, 2007) or vacation/leisure (Wilensky, 1960), in a harmonising rather than inverse manner.

Spill-over theory suggests that some individuals may want to engage in similar behaviours and activities in both home and holiday settings. Burch's (1969) approach is in line with the postmodern conceptualisation of the tourist experience and links everyday life and tourism behaviour. In the present study, spill-over represented the generality of behaviours exhibited while staying in an Airbnb and while at home. Some studies have supported Burch's (1969) spill-over theory. For example, Sthapit and Björk (2017) found that tourists showed a similar behavioural pattern when carrying out activities at home and at their destination, such as visiting museums, skiing, hiking, shopping and swimming.

\section{Tourism experiences, emotions (positive and negative) and memories}

Tourism consumption, as a typical experiential purchase, is an emotional experience (Stone et al., 2018). In the context of tourism, emotions refer to tourists' emotional states during a tourism experience (Chang et al., 2020). Emotions are specific and intentional - triggered by a particular environment, event or object and with regard to something (Bagozzi et al., 1999). Emotions experienced are an indispensable component of a tourism experience and such experiences often include satisfying and pleasurable emotions (Aho, 2001).

Emotions play a central role in defining memorable experiences (Tung and Ritchie, 2011). In addition, emotions can affect both memory encoding and retrieval processes (Tung and Ritchie, 2011). Some studies have identified positive feelings, such as excitement, happiness, pleasure, interest and relaxation, as tourism-related emotions (Kim et al., 2016). On the one hand, positive emotions arising from the holiday experience enhance the memorability of a trip (Tung and Ritchie, 2011). On the other hand, travel can be stressful and associated with negative emotional outcomes (Mackenzie and Kerr, 2013), resulting in negative memorable experiences.

After the completion of a journey, the perception of the tourist experience is influenced by memory (Erll, 2011). The tourist experience is routinely positioned as a generator of memories and collecting memories is widely understood as the very purpose of holidays (Edensor, 1998). Episodic memory, which includes individuals' long-term storage of factual memories concerning personal experiences, is considered to be the most relevant type of long-term memory in the study of tourists' experiences (Larsen, 2007).

\section{Methodology}

\section{Sampling, data collection and analysis}

An empirical study of a qualitative nature was conducted using a self-administered, openended questionnaire to expand on the literature on MTEs and Airbnbs. The justification for the use of open-ended questions in the questionnaire is that such questions do not provide 
participants with participants with a predetermined set of answer choices, instead allowing the participants to provide responses in their own words (Allen, 2017). The target population was international tourists who had stayed in an Airbnb in the past three years. Convenience sampling was used, as it is cheap, efficient and simple to implement.

Data were collected using two different sources for triangulation purposes, referred to as Studies 1 and 2. First, using the authors' personal networks, an email containing a link to the questionnaire was sent to 200 people in March 2020. The personal networks from which the sample was drawn for study 1 were made up of professionals and did not include very close social contacts (friends, family). Second, data were gathered via Amazon Mechanical Turk (MTurk) during April 2020 and were active for two weeks. Two data sets were used with the purpose of strengthening the study's validity through data triangulation (Decrop, 1999).

Respondents were asked to recollect their latest Airbnb experiences, and at the beginning of the survey, they were told that it was critical to read the instructions carefully. The first section included demographic variables (age, gender, marital status and nationality) and travel characteristics (e.g. destination visited, purpose of visit). The second section related to the booking and on-site Airbnb experience (duration of stay, number of people in the travel party, purpose of the trip, number of Airbnb bookings in the past 12 months, activities undertaken during the Airbnb stay, emotions regarding the Airbnb experience). The last section included one question on what made this experience most memorable. The question, When did you take this trip? was used as an attention check to effectively identify and remove poor quality participants from the data as the survey targeted international tourists who had stayed in an Airbnb in the past three years.

This study's key findings were based on qualitative responses to survey questions considering activities, emotions and memories. The data analysis adopted a grounded theory research design (Glaser and Strauss, 1967) and Strauss and Corbin's (1990) three recommended steps for a grounded theory approach were followed. The first step was to scan the collected data to obtain a broad understanding of them. The second step was to review the data and listing categories. The last step involved manual coding. As Strauss and Corbin (1990) recommended, three types of coding were used: open coding; axial coding; and selective coding.

\section{Findings and discussion \\ Profile of the respondents}

In the first study, of the 97 respondents, 52 were male and 45 were female, and they represent 37 different nationalities, with ages ranging from 18 to 61 years old. The respondents' household structures varied. Most were single (51), followed by those that were married (24), engaged (10), co-habiting (8) and divorced (2).

In the second study, of the 64 respondents, 38 were male and 26 were female, representing three different nationalities. The majority of the respondents were Americans (52), and their ages ranged from 18 to 69 years old. The majority of the respondents were married (36), followed by those that were single (24), engaged (2), co-habiting (1) and divorced (1).

\section{Profile of travel behaviours}

In Study 1, respondents' most recent Airbnb stays had taken place between May 2017 and March 2020. The destinations ranged from Barcelona (Spain) to Kuta (Indonesia). The duration of the stay ranged from 1-14 days, while the majority reported spending less than four days (63) in an Airbnb. The size of the travel party ranged from one to nine people, and many of the respondents had travelled in groups of more than two people (48). About $86 \%$ had travelled for leisure and the rest for business. When asked, "How many Airbnb 
bookings have you made in the past 12 months?," the most common responses were one (26) and four (14). Only $11 \%$ had booked the same Airbnb rental property before.

In Study 2, respondents' most recent Airbnb stays occurred between December 2018 and March 2020. The destinations ranged from Los Angeles (USA) to Bangalore (India). The duration of the stay ranged from 1-120 days, while the majority reported spending more than five days (34) at their destination. The size of the travel party ranged from one to 52 people, and many of the respondents had travelled in groups of more than two people (28), followed by two people (26) and alone (11). Most respondents had travelled for leisure/ tourism (48), while some mentioned business (16). When asked, "How many Airbnb bookings have you made in the past 12 months?," the most common responses were two (30) and three (11). About $36 \%$ had booked the same property before.

\section{Activities while staying in an Airbnb}

In response to the question, "Name some activities that you did while recently staying in an Airbnb. Did you do similar or different activities to those that you do at home?," most of Study 1's respondents mentioned doing the same or similar activities as they do at home, especially preparing their own meals (mentioned by nearly $60 \%$ of respondents). Phrases in the answers included "cooking with friends," "preparing food together," "prepared own meals," "making breakfast," "cooking different dishes," "cooking meals with local ingredients," "enjoyed cooking my own meal" and "make breakfast." About 11\% reported spending time with each other, while only about $3 \%$ mentioned watching TV and playing games.

A similar trend was identified in Study 2. Specifically, some mentioned cooking (23\%) and watching TV (11\%). Between $6 \%$ and $8 \%$ of the respondents mentioned: spending time with each other, doing physical exercise, watching movies and playing games. Many of those on a business trip (19\%) did not spend much time at the Airbnb. The significance of cooking while staying at an Airbnb is emphasised by the following interpretive codes: "cooked dinner in the Airbnb," "we cooked a lot," "cooked several meals for friends" and "cooked dinner for myself daily."

In both studies, cooking appeared to be significant in guests' recollections of Airbnb experiences. This finding supports Burch's (1969) spill-over theory and indicates a spillover in terms of activities from home to away contexts, which are likely not found in traditional hotel lodgings.

\section{Emotions linked to the Airbnb experiences and their sources}

In response to the questions, "Which strong positive or negative emotions did you feel during your Airbnb experience? What aroused these emotions?," most of the respondents in study 1 mentioned positive emotions. Specifically, they mentioned joy (45), love (11), contentment (3), comfort (4), anger (4), excitement (3) and interest (4). Seventeen respondents reported no strong emotions. Relating to joy, respondents mentioned numerous reasons for having experienced this emotion during their on-site Airbnb experiences, such as "travel companion," "because of spending time with friends," "friendly host," "host's hospitality," "clean room," "location," "beautiful location close to the city centre" and "homely feeling." Three particular responses further emphasise this. One respondent answered, "I felt joy in terms of the host's manners and guidance when exploring the city [...]" (male, Cypriot, visiting the UK). The second stated, "I felt joy because I was there with my friends [...]" (female, Finnish, visiting Hualien). The third clarified, "I felt joy because the room was clean and the host was friendly" (female, Chinese, visiting Kaunas). In addition, "lack of towels and toilet paper," "dirty room," "lazy host" and "lack of assistance and communication from the host" contributed to anger among some 
respondents. Moreover, a common element that contributed to both positive and negative emotions was the host's hospitality, which may vary greatly among hosts.

In study 2, many respondents mentioned joy (19), comfort (12), love (8) and excitement (5). Eighteen respondents reported no strong emotions. The sources of joy included "spending time together," "bonding," "location," "feeling of home," "beautiful decoration of the room" and "size of the apartment." This is further highlighted by the answers of three respondents. One said, "It was positive - joy. We had a great time together, and it was a wonderful experience [...]" (male, American, visiting Austin). Another said, "We experienced a lot of joy. We had a lot of fun with our kids and it was a nice place to stay during Christmas [...] pure enjoyment" (female, American, visiting Idyllwild). The sources of negative emotion of anger were a "poorly maintained apartment" and "bed bugs."

In response to the question, "How was your recent Airbnb experience?," 96\% of the respondents in Study 1 reported that it was positive, while the remainder reported negative experiences because of hosts' inappropriate behaviour. Some keywords used to describe their stays at Airbnbs included "good experience," "awesome," "very smooth," "overall great," "so much fun," "just amazing," "very positive," "pretty good," "pleasant one," "really nice," "nice overall," "very pleasant" and "well organised and arranged." One response further highlights this. One respondent stated, "Just amazing. Lovely host. We stayed in an artist's studio, which was decorated nicely. The host even took us to the bus station the next day. She did more than we expected" (Male, Turkish, visiting Paris).

In Study 2, 95\% of the respondents mentioned that their recent Airbnb experiences were positive while the remainder had negative experiences during their stay. The keywords were similar to those in Study 1. One sample response was as follows: "It was amazing. We were staying at a big property surrounded by the natural terrain in beautiful Pacific Palisades overlooking Santa Monica and West Los Angeles. It was a complete escape from the business of the city. The place was extremely with comfortable amenities and an incredibly quiet atmosphere. We fell in love with the place" (female, American, visiting Los Angeles). The second said, "It was good. The room was clean, the host was responsive and I did not have any issues with the location [... ]" (male, American, visiting San Diego).

\section{Memorable components}

In response to the question, "What made the experience the most memorable?," many of the respondents in study 1 replied by saying with socialising and bonding (30) and the location of the Airbnb rental property (23). This was indicated by keywords and phrases, such as "being with my four best friends," "being with my family made it memorable," "because of the people I was travelling with," "because of the time we spent together," "was memorable because I spent some quality time with a special person," "it was the location," "nice neighbourhood," "the location in the city centre" and "the location of the flat." This is further emphasised by two responses. One respondent replied, "it was memorable because of the people I was travelling with" (female, Taiwanese, visiting Rovinj). The second stated, "It was mainly because of the location of this place, which was in the countryside and surrounded by forests and ponds [...]" (male, Azerbaijani, visiting Jõgeva). Others cited the host's hospitality (23) and a homely feeling (17) as contributing to their positive memories of their Airbnb experiences, while the poor condition of rooms created negative memorable experiences (4).

In Study 2, many of the respondents mentioned the host's hospitality (16), the location of the rental property (14) and spending time with family and friends (13) as contributing to a positive memorable Airbnb experience. The significance of the host's hospitality, the location and spending time with family and friends is indicated by the following interpretive codes: "because of the host," "very good host," "host was super helpful," "truly the best place to hangout," "superb location," "because my friends and I spent the holiday together" 
and "family time together." This is further emphasised by the responses of three respondents. One said, "I have to say what made my experience memorable was the very good host. The room was clean, and the host left us beads and trinkets because it was close to Mardi Gras time" (female, American, visiting New Orleans). Others said, "The location made it memorable. This particular Airbnb was in a very quiet neighbourhood, so much of the noise associated with a hotel/motel was not present. Staying in a hotel/motel is essentially people sharing a noisy bedroom" (female, American, visiting Cheyenne); and "It was memorable because I was able to spend time with my family. It was so much fun and enjoyable. I can feel it right now. It was very helpful for bonding with one another" (male, American, visiting Fort Worth). Others mentioned home amenities (8) and a homely feeling (4), while dishonest hosts (2) created negative memorable experiences.

Overall, based on the two studies, socialising and bonding with friends and family members, the location, the host's hospitality, a homely feeling, home amenities, the poor condition of the Airbnb rental unit and a dishonest host contributed to a memorable Airbnb experience.

Some studies have indicated that the social origins of pleasurable and memorable experiences are connected, especially with regard to engagement with friends and family (Dube and LeBel, 2003), and this seems to apply to Airbnb experiences as well. In addition, studies have found that location is one of the attributes linked to travellers' memorable Airbnb experiences (Sthapit and Jiménez-Barreto, 2018). This finding supports studies that recognise the significance of hospitality in terms of the host's behaviour (Lalicic and Weismayer, 2018) and a feeling of home (Zhu et al., 2019) while staying at an Airbnb. This homely feeling is considered key to experiencing a fulfilling stay in a P2P accommodation (Zhu et al., 2019). Feeling at home is linked to home benefits, including the physical environment, physical amenities and physical utility of an Airbnb (So et al., 2018), and these attributes enhance the customer experience (Guttentag and Smith, 2017).

The findings indicate the significance of socialising and bonding, reflected through spending time with "friends and family members" in respondents' recollections of their memorable Airbnb experiences, while very few mentioned "host-guest time/interactions." Thus, for many respondents, the Airbnb experience involved spending time with friends and family members and not meaningful interactions with hosts and locals, contradicting some recent studies (Mody et al., 2017). This finding also contradicts studies indicating that the Airbnb experience is embedded in host-guest interactions (Sthapit and Jiménez-Barreto, 2018) and that host-guest contact is common in Airbnb accommodation (Lin et al., 2019). Moreover, the findings support some studies that indicate that location is one of the most critical factors of business success in terms of Airbnbs (Cheng and Jin, 2019).

Some studies have indicated that a poorly maintained room has a negative impact on service quality attributes, such as facility condition (Ert et al., 2016) and the Airbnb accommodation experience (Sthapit et al., 2020). The accommodation provided by the host is considered a key service quality dimension of an Airbnb (Sthapit and Björk, 2020). The findings support studies indicating that the physical environment (Cheng and Jin, 2019) - is considered crucial for guests staying in Airbnb rental properties. This may indicate the potential of Airbnb environments in terms of creating many more negative memories than other tourist experiences. One reason for the poor condition of the rooms that some respondents experienced is the fact that Airbnb hosts are not trained service providers (Sthapit and Jiménez-Barreto, 2018).

\section{Conclusion}

Three main conclusions can be drawn from the research. First, among leisure travellers, most reported doing the same or similar activities while staying at Airbnbs that they do at home. This contradicts studies indicating that guests are drawn to Airbnbs because they 
seek novelty during their stays abroad (So et al., 2018). In the same vein, studies have indicated that performing familiar activities represents an affinity for convenience and minimal planning (LaMondia and Bhat, 2012) and offers stability, comfort and relaxation in a new setting (Edensor, 2001). In the Airbnb context, some studies have shown that familiarity provides customers (guests) with a feeling of security and comfort, which increases their perceived control over their behaviour (Mao and Lyu, 2017). In addition, the results of the present study suggest that the spill-over effect is more prevalent in the Airbnb context than in other accommodation types, as one often travels from one's own home to another's home (not a hotel room). In other words, an Airbnb stay may correspond more to staying in somebody's home than a hotel stay, and this might offer the guest more freedom, for example, to do his or her own cooking. This highlights the importance of context in contributing to spill-over effects.

The present study argues that an on-site Airbnb experience blurs the differences between home (leisure) and away (tourism). This finding also problematises the gap in polarity between home and away, aligning with the post-modern theory of the tourism experience, which suggests that daily-life experiences cannot be separated from tourism experiences (Uriely, 2005). In fact, a de-differentiation may occur that challenges the notion of liminality, whereby a variety of habitual behaviours occur during an Airbnb stay. For many respondents, the Airbnb experience was less about escaping from home routines and more about the enactment of various mundane activities embedded in day-to-day life, while others may have experienced novelty by engaging in routine activities in a new setting. Thus, rather everydayness and novelty seeking may co-exist in an Airbnb environment.

Second, emotions with regard to Airbnbs focussed on joy. This finding supports studies indicating that guests predominantly experience positive emotions while staying at Airbnbs (Camilleri and Neuhofer, 2017) and that positive emotions, such as happiness, are more common than negative emotions during a tourism experience. In addition, the negative emotion of anger was not common in the recollections, as tourist activities mainly encourage guests to relax and engage in social experiences (Servidio and Ruffolo, 2016).

Third, this study adds to the existing literature on MTEs and Airbnbs and proposes a new conceptual framework of memorable Airbnb experience, which comprises several components: socialising and bonding with friends and family members, location, the host's hospitality, a homely feeling, home amenities and (to a lesser extent) negative experiences (e.g. property condition; poor or dishonest host) (Figure 1). Thus, although the term "memorable" has a positive connotation, this finding suggests that some travellers also recall the less positive experiences of an Airbnb stay. Besides the location component, the findings differ in terms of Sthapit and Jiménez-Barreto's (2018) other memorable Airbnb component, that is, social interaction with the host. Contrary to their study and others (Cheng and jin, 2019), there was very little evidence of tourist-host interactions, thus lending support to So et al.'s (2018) study. On the contrary, many respondents in this study recalled socialising and bonding with friends and family members as making their Airbnb experience memorable. These bonding occasions between travel parties also help to explain the emotion of joy observed in the Airbnb experiences. Overall, the positive memories focussed on travel companions, the location and the host's hospitality, with a lesser percentage acknowledging a homely feeling and negative experiences linked to the condition of the apartment and the host's behaviour.

This study also has managerial implications for both Airbnb's hosts. Given that travellers mostly recalled mundane activities, such as cooking, hosts offering kitchen amenities in their accommodation might have an advantage over other hosts that offer merely a room with no amenities. Thus, Airbnb rental properties should offer basic home amenities such as a kitchen, a washing machine and a dryer. Therefore, this information with photos should be highlighted in hosts' profiles. In addition, besides spending time with family and friends while staying in an Airbnb rental property, a friendly host, the host's hospitality, a clean 


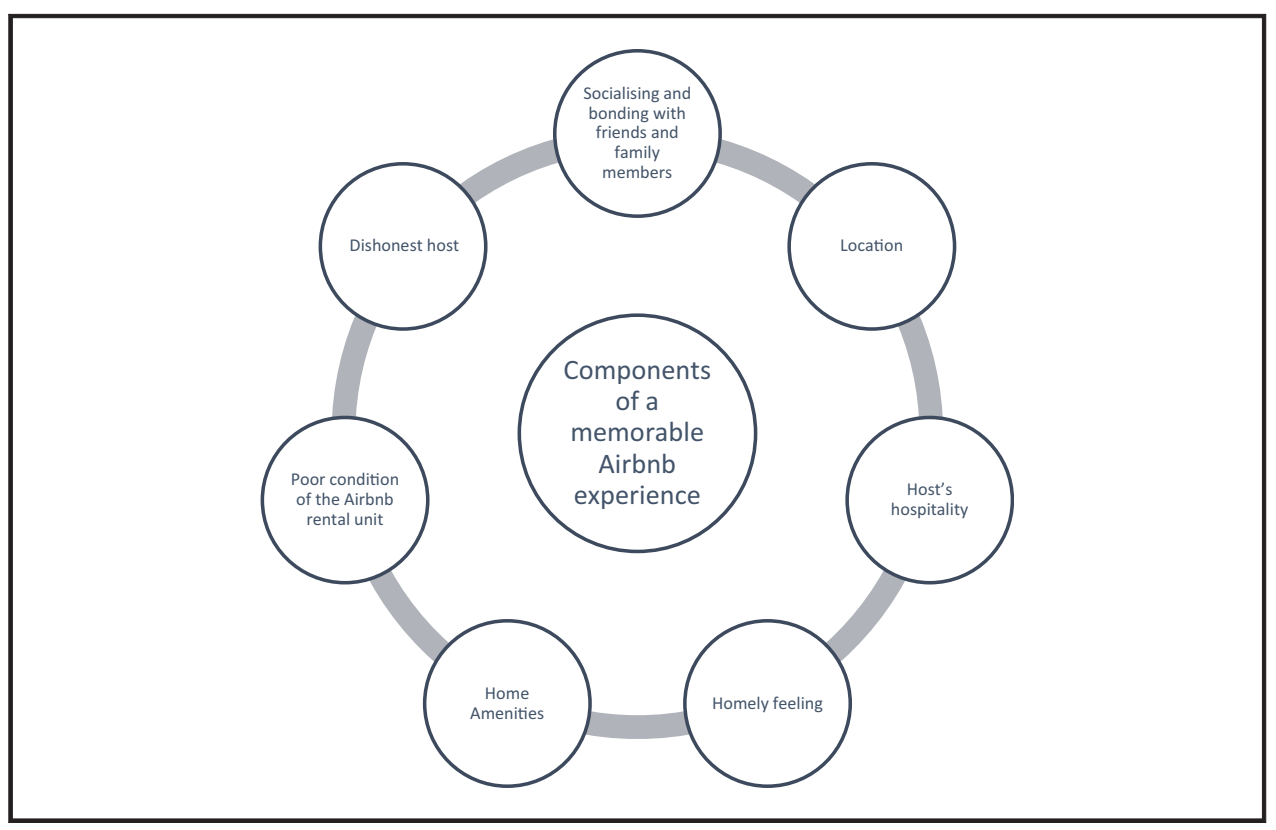

room, the location and a homely feeling contributed to the feeling of joy experienced by guests when recalling what made the experience most memorable. Therefore, Airbnb should clearly define hosts' tasks and responsibilities, and hosts should treat guests in a friendly manner, which includes resolving any problems they face in relation to the rental property. Hosts who are frequently reported as dishonest and unprofessional towards guests should be banned from hosting on Airbnb. There should also be a focus on the location of the rental property and pictures of the facilities and information about the property's proximity to nearby tourist attractions, restaurants and transportation should be included. Moreover, as the poor condition of a room contributed to a negative memorable Airbnb experience, Airbnb's management should provide hosts with training on maintaining service quality and with a checklist to ensure consistent quality standards across listings. Hosts must also be monitored to ensure they maintain service quality standards. Hosts must be held accountable in situations where things go wrong because of them, for example, if guests complain about poor condition of the Airbnb rental unit.

Despite these contributions, this study has some limitations. First, this study's findings are exploratory in nature, and its generalisability is limited. Second, as with any research study, the number of participants was limited. Third, the data were collected during the post-visit stage to assess travellers' memorable Airbnb experiences and, as such, relied on variable periods of memory. Studies have shown that recalled tourism experiences are significantly different from the on-site ones that tourists had. People reconstruct their tourism experiences forgetting disappointments (Mitchell et al., 1997). Therefore, to avoid this incongruence between remembered experiences and on-site experiences, future studies should involve interviews with tourists immediately after their visits. Fourth, the use of openended survey questions is another limitation of this study that might have had an impact on the richness of the gathered data. This research limitation can be overcome by adopting a greater array of research methods, for example, focus groups, in-depth interviews, observations and/or diaries obtained from sampled individuals who record their Airbnb experiences soon after their trips. Fifth, another limitation is the double-barrelled questions used in the open-ended survey questionnaire, which might have led respondents to carry out hoc sense making. Thus, future studies would benefit from the use of single questions. 
Sixth, the spill-over theory includes emotional/affective and attitudinal spill-over from one domain to another, while this study was restricted to activities undertaken during an on-site Airbnb experience, which is one of the limitations. Future studies could provide a list of emotions and include questions about the frequency and intensity, including the use of quantitative methods to measure activities while staying at an Airbnb. This study suggested that many activities were undertaken but were not committed to memory. Further, researchers could extend the current discussion on memorable Airbnb experiences and explore the possible spill-over from away to home, including the impact of a memorable Airbnb experience on the guest's well-being while at home. This could provide a broader understanding of the interlinkages between the different concepts of spill-over theory, memorability and wellbeing. In addition, elements of MTEs (such as those defined by Kim et al., 2012) could be further explored in novel environments, such as Airbnbs and compared with other travel environments.

\section{References}

Aho, S.K. (2001), "Towards a general theory of touristic experiences: modelling experience process in tourism", Tourism Review, Vol. 56 Nos 3/4, pp. 33-37.

Airbnb (2019), "Airbnb hosts share more than six million listings around the world", available at: https:// press.airbnb.com/airbnb-hosts-share-more-than-six-million-listings-around-theworld (accessed 10 February 2020).

Allen, M. (2017), The SAGE Encyclopedia of Communication Research Methods, Sage, London.

Bagozzi, R.P., Gopinath, M. and Nyer, P. (1999), "The role of emotions in marketing", Journal of the Academy of Marketing Science, Vol. 27 No. 2, pp. 184-206.

Boswell, W.R. and Olson-Buchanan, J.B. (2007), "The use of communication technologies after hours: the role of work attitudes and work-life conflict”, Journal of Management, Vol. 33 No. 4, pp. 592-610.

Burch, W.R. (1969), "The social circles of leisure: competing explanations", Journal of Leisure Research, Vol. 1 No. 2, pp. 125-147.

Camilleri, J. and Neuhofer, B. (2017), "Value co-creation and co-destruction in the Airbnb sharing economy", International Journal of Contemporary Hospitality Management, Vol. 29 No. 9, pp. 2322-2340.

Chandralal, L., Rindfleish, J. and Valenzuela, F. (2015), "An application of travel blog narratives to explore memorable tourism experiences", Asia Pacific Journal of Tourism Research, Vol. 20 No. 6, pp. 680-693.

Chang, S.-Y., Tsaur, S.-H., Yen, C.-H. and Lai, H.-R. (2020), "Tour member fit and tour member-leader fit on group package tours: influences on tourists' positive emotions, rapport, and satisfaction”, Journal of Hospitality and Tourism Management, Vol. 42, pp. 235-243.

Cheng, M. and Jin, X. (2019), "What do airbnb users care about? An analysis of online review comments", International Journal of Hospitality Management, Vol. 76, pp. 58-70.

Cohen, E. (1972), "Toward a sociology of international tourism", Social Research, pp. 164-182.

Decrop, A. (1999), "Triangulation in qualitative tourism research", Tourism Management, Vol. 20 No. 1, pp. 157-161.

Dogru, T., Hanks, L., Mody, M., Suess, C. and Sirakaya-Turk, E. (2020), "The effects of airbnb on hotel performance: evidence from cities beyond the United States", Tourism Management, Vol. 79, p. 104090.

Dube, L. and LeBel, J. (2003), "The content and structure of laypeople's concept of pleasure", Cognition \& Emotion, Vol. 17, pp. 263-295.

Edensor, T. (1998), Tourists at the Taj: Performance and Meaning at a Symbolic site, Routledge, London.

Edensor, T. (2001), "Performing tourism, staging tourism: (re)producing tourist space and practice", Tourist Studies, Vol. 1 No. 1, pp. 59-81.

Erll, A. (2011), Memory in Culture, Palgrave, London. 
Ert, E., Fleischer, A. and Magen, N. (2016), "Trust and reputation in the sharing economy: the role of personal photos in Airbnb", Tourism Management, Vol. 55, pp. 62-73.

Glaser, B.G. and Strauss, A. (1967), The Discovery of Grounded Theory: Strategies for Qualitative Research, Aldine, Chicago.

Guttentag, D. and Smith, S. (2017), "Assessing airbnb as a disruptive innovation relative to hotels: substitution and comparative performance expectations", International Journal of Hospitality Management, Vol. 64, pp. 1-10.

Kensigner, E.A. and Schacter, D.L. (2006), "When the red sox shocked the yankees: comparing negative and positive memories", Psychonomic Bulletin \& Review, Vol. 13 No. 5, pp. 757-763.

Kim, D., Lee, C.K. and Sirgy, M.J. (2016), "Examining the differential impact of human crowding versus spatial crowding on visitor satisfaction at a festival", Journal of Travel \& Tourism Marketing, Vol. 33 No. 3, pp. 293-312.

Kim, J.H., Ritchie, J. and McCormick, B. (2012), "Development of a scale to measure memorable tourism experiences", Journal of Travel Research, Vol. 51 No. 1, pp. 12-25.

Lalicic, L. and Weismayer, C. (2018), "A model of tourists' loyalty: the case of airbnb", Journal of Hospitality and Tourism Technology, Vol. 9 No. 1, pp. 78-90.

LaMondia, J. and Bhat, C. (2012), "A conceptual and methodological framework of leisure activity loyalty accommodating the travel context", Transportation, Vol. 39 No. 2, pp. 321-349.

Larsen, S. (2007), "Aspects of a psychology of the tourist experience", Scandinavian Journal of Hospitality and Tourism, Vol. 7 No. 1, pp. 7-18.

Larsen, J., Urry, J. and Axhausen, K.W. (2007), "Networks and tourism: mobile social life", Annals of Tourism Research, Vol. 34 No. 1, pp. 244-262.

Lee, T.H. and Crompton, J. (1992), "Measuring novelty seeking in tourism", Annals of Tourism Research, Vol. 19 No. 4, pp. 732-751.

Lin, P.M.C., Fan, D.X., Zhang, H.Q. and Lau, C. (2019), "Spend less and experience more: understanding tourists' social contact in the airbnb context", International Journal of Hospitality Management, Vol. 83, pp. 65-73.

McCabe, S. (2002), "The tourist experience and everyday life", Dann, G.M.S. (Ed.), The Tourist as a Metaphor of the Social World, CABI Publishing, Wallingford, pp. 61-75.

Mackenzie, S.H. and Kerr, J.H. (2013), "Stress and emotions at work: an adventure tourism guide's experiences”, Tourism Management, Vol. 36, pp. 3-14.

Mao, Z. and Lyu, J. (2017), "Why travelers use airbnb again?", International Journal of Contemporary Hospitality Management, Vol. 29 No. 9, pp. 2464-2482.

Mitchell, T.R., Thompson, L., Peterson, E. and Cronk, R. (1997), "Temporal adjustments in the evaluation of events: the rosy view", Journal of Experimental Psychology, Vol. 33 No. 4, pp. 421-448.

Mody, M.A., Suess, C. and Lehto, X. (2017), "The accommodation experiencescape: a comparative assessment of hotels and airbnb", International Journal of Contemporary Hospitality Management, Vol. 29 No. 9, pp. 2377-2404.

Quan, S. and Wang, N. (2004), "Towards a structural model of the tourist experience: an illustration from food experience in tourism", Tourism Management, Vol. 25 No. 3, pp. 297-305.

Rothbard, N.P. and Dumas, T.L. (2006), "Research perspectives: Managing the work-home interface", in Jones, F., Burke, RJ and Westman, M. (Eds), Work-Life Balance. A Psychological Perspective, Psychology Press, Hove, pp. 71-89.

Servidio, R. and Ruffolo, I. (2016), "Exploring the relationship between emotions and memorable tourism experiences through narratives", Tourism Management Perspectives, Vol. 20, pp. 151-160.

Smith, W.W., Pitts, R.E. and Litvin, S.W. (2012), "Travel and leisure activity participation", Annals of Tourism Research, Vol. 39 No. 4, pp. 2207-2210.

So, K.K.F., Oh, H. and Min, S. (2018), "Motivations and constraints of airbnb consumers: findings from a mixed-methods approach", Tourism Management, Vol. 67, pp. 224-236.

Sthapit, E. (2019), "My bad for wanting to try something unique: sources of value co-destruction in the airbnb context", Current Issues in Tourism, Vol. 22 No. 20, pp. 2462-2465. 
Sthapit, E. and Björk, P. (2017), "Activity participation home and away - examining the spill-over theory among families on holiday", Anatolia, Vol. 28 No. 2, pp. 209-223.

Sthapit, E. and Björk, P. (2020), "Interactive value formation: drivers and outcomes from airbnb guests' perspectives", Scandinavian Journal of Hospitality and Tourism, Vol. 21 No. 2.

Sthapit, E. and Jiménez-Barreto, J. (2018), "Exploring tourists' memorable hospitality experiences: an airbnb perspective", Tourism Management Perspectives, Vol. 28, pp. 83-92.

Sthapit, E., Björk, P., Jiménez-Barreto, J. and Stone, M.J. (2020), "Spillover effect, positive emotions and savouring processes: Airbnb guests' perspective”, Anatolia, Vol. 32 No. 1, pp. 33-45.

Stone, M.J., Migacz, S. and Sthapit, E. (2021), "Connections between culinary tourism experiences and memory", Journal of Hospitality \& Tourism Research.

Stone, M.J., Migacz, S. and Wolf, E. (2018), "Beyond the journey: the lasting impact of culinary tourism activities", Current Issues in Tourism, Vol. 22 No. 2, pp. 147-152.

Strauss, A. and Corbin, J. (1990), Basics of Qualitative Research: Grounded Theory Procedures and Techniques, Sage, Newbury Park.

Tung, V.W.S. and Ritchie, J.B. (2011), "Exploring the essence of memorable tourism experiences", Annals of Tourism Research, Vol. 38 No. 4, pp. 367-1386.

Uriely, N. (2005), "The tourist experience: conceptual developments", Annals of Tourism Research, Vol. 32 No. 1, pp. 199-216.

Wilensky, H.L. (1960), "Work career and social integration", International Journal of Social Science, Vol. 12, pp. 543-560.

Zhu, Y., Cheng, M., Wang, J., Ma, L. and Jiang, R. (2019), "The construction of home feeling by airbnb guests in the sharing economy: a semantics perspective", Annals of Tourism Research, Vol. 75, pp. 308-321.

\section{Further reading}

Ju, Y., Back, K.-J., Choi, Y. and Lee, J.-S. (2019), "Exploring airbnb service quality attributes and their asymmetric effects on customer satisfaction", International Journal of Hospitality Management, Vol. 77, pp. 342-352.

\section{Corresponding author}

Erose Sthapit can be contacted at: Erose.Sthapit@haaga-helia.fi

For instructions on how to order reprints of this article, please visit our website: www.emeraldgrouppublishing.com/licensing/reprints.htm

Or contact us for further details: permissions@emeraldinsight.com 